\title{
CREEP OF ICE UNDER LOW STRESS
}

\author{
By Malcolm Mellor and Richard Testa \\ (U.S. Army Terrestrial Sciences Center, Hanover, New Hampshire 03755, U.S.A.)
}

\begin{abstract}
Uniaxial compressive creep tests on fine-grained polycrystalline ice indicate that secondary strain-rate is proportional to $\sigma^{1,8}$, where $\sigma$ is applied stress, for the range $0.1<\sigma<0.5 \mathrm{kgf} / \mathrm{cm}^{2}$ $\left(\right.$ 1 $\left.<<\sigma<50 \mathrm{kN} / \mathrm{m}^{2}\right)$. On the basis of the present tests, earlier results suggesting linear viscous behaviour at low stress are believed to be invalid.

RÉsumÉ. Fluage de la glace sous contrainte faible. Des expériences de fluage sous contrainte compressive uniaxiale d'échantillons de glace polycristalline à grains fins indiquent que la vitesse de déformation secondaire est proportionnelle à $\sigma^{1,8}$, où $\sigma$ est le contrainte pour l'intervalle $0,1<\sigma<0,5 \mathrm{kgf} / \mathrm{cm}^{2}($ Io $<\sigma<50$ $\mathrm{kN} / \mathrm{m}^{2}$ ). Sur la base de ces expériences, on peut penser que des résultats antérieurs suggérant un comportement visqueux linéaire sous faible contrainte n'ont pas de poids.
\end{abstract}

Zusammenfassung. Kriechen des Eises bei geringer Beanspruchung. Untersuchungen des Kriechens von feinkörnigem, polykristallinem Eis unter einachsiger Druckspannung zeigen, dass die sekundäre Verformungsgeschwindigkeit im Bereich $0,1<\sigma<0,5 \mathrm{kp} / \mathrm{cm}^{2}$ (10 $\left.<\sigma<50 \mathrm{kN} / \mathrm{m}^{2}\right)$ proportional zu $\sigma^{1,8}$ ist, wobei $\sigma$ die angewandte Druckspannung bedeutet. Im Lichte der vorliegenden Untersuchungen scheinen frühere Ergebnisse, die bei geringer Beanspruchnug ein lineares viskoses Verhalten annahmen, ihre Gültigkeit zu verlieren.

\section{INTRODUCTION}

The stress/strain-rate relation for polycrystalline ice creeping steadily under low stress has never been firmly established. Ample data exist for creep under stresses in the range $\mathrm{I}$ to $20 \mathrm{kgf} / \mathrm{cm}^{2}$ (O.I to $2 \mathrm{MN} / \mathrm{m}^{2}$ ), but for lower stresses, which are representative of deviator stresses in glaciers, there is a shortage of experimental information.

Most of the available data suggest that the dependence of strain-rate upon stress becomes weaker as stress level decreases, and there has been speculation as to whether or not the stress/ strain-rate relation becomes linear at low stress. Accepted at face value, experiments by Butkovich and Landauer (1960) show that strain rate is proportional to stress in the stress range 0.02 to $0.2 \mathrm{kgf} / \mathrm{cm}^{2}$ ( 2 to $20 \mathrm{kN} / \mathrm{m}^{2}$ ). Likewise, results by Mellor and Smith ( 1967 ) tend to support the idea of a transition to linear viscous behaviour below about $\mathrm{I} \mathrm{kgf} / \mathrm{cm}^{2}$ ( 100 $\mathrm{kN} / \mathrm{m}^{2}$ ). However, in neither of these cases were strain-rates compared for the same degree of strain in the ice, and there remained a definite possibility that secondary creep rates for samples under higher stresses and temperatures were being compared with primary creep rates for those samples subject to low stresses and temperatures. Furthermore, in most of the tests made by Butkovich and Landauer, grain size was comparable to sample size.

Bromer and Kingery (I968) apparently found a linear stress/strain-rate relation for polycrystalline ice in the temperature range $-3^{\circ}$ to $-13^{\circ} \mathrm{C}$, but the duration of their tests was not given. The sample creep curve shown in the paper had a duration of only $\mathrm{r}$ ooo min, which seems too short a period for establishment of secondary creep in the range of stress and temperature considered. work.

In the present tests, an attempt was made to avoid some of the flaws which exist in earlier

\section{Test Procedures}

Homogeneous, isotropic samples of fine-grained polycrystalline ice were prepared by packing sieved ice grains into a vibrated mold and saturating with degassed distilled water before freezing. Size of the finished cylindrical sample prior to loading was $3.59 \mathrm{~cm}$ diameter by $9.98 \mathrm{~cm}$ long, and the constituent randomly oriented crystals were approximately $\mathrm{I} \mathrm{mm}$ in diameter. Ice density was $0.90 \mathrm{Mg} / \mathrm{m}^{3}$. 
The cylindrical samples were loaded axially in compression by dead weight, using a simple lever arrangement. Tests were made at axial stresses of 0.093 and $0.43 \mathrm{kgf} / \mathrm{cm}^{2}$ (9. I and $\left.42 \mathrm{kN} / \mathrm{m}^{2}\right)$. The upper loading plate was free to rotate and translate in all directions. Three identical samples were tested simultaneously under identical test conditions. Axial deformations of the samples were detected by Statham Type $\mathrm{G}_{7} \mathrm{~A}$ strain gages, which were read on a Baldwin-Lima-Hamilton $\mathrm{SR}_{4}$, Type NB, strain indicator. The gage readings could be resolved to $4 \times 1^{-6} \mathrm{~cm}$ which, taking into account the $2 \times$ lever multiplication factor of the loading device, represented a displacement of $2 \times 10^{-6} \mathrm{~cm}$ at the sample, or an axial strain of $2 \times \mathrm{IO}^{-7}$. The gages were calibrated individually before and after the tests.

Test samples were housed in a Styrofoam cabinet which was refrigerated by its surroundings, i.e. a cold room regulated to $-10^{\circ} \mathrm{C}$. Temperature inside the box was regulated by a heating unit and fan actuated through a relay by a Philadelphia Microset mercury regulator.

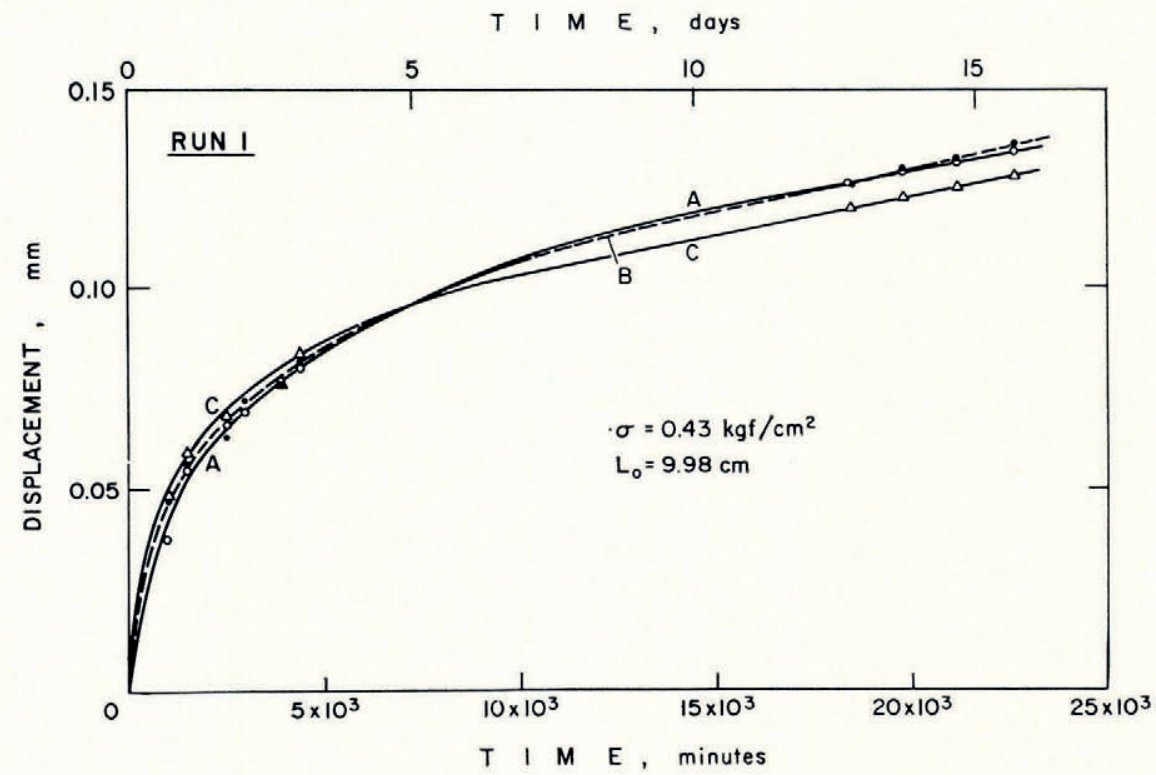

Fig. I. Low-stress creep curves for fine-grained ice whose crystal orientation was initially random. Test temperature $-2.06^{\circ} \mathrm{C}$. Constant axial compressive stress of $0.43 \mathrm{kgf} / \mathrm{cm}^{2}\left(4^{2} \mathrm{kN} / \mathrm{m}^{2}\right)$ on ice which had not been previously loaded.

The rated response of the regulator was \pm o.o I deg., and variation of air temperature in the immediate vicinity of the test samples was always less than $0.1 \mathrm{deg}$. To avoid evaporation from the sample, its surface was wrapped with a thin film of plasticized polyvinylidene chloride (sandwich wrap), and copious quantities of loose snow were placed inside the test cabinet to saturate the air.

Test temperature was $-2.06^{\circ} \mathrm{C}$. A high temperature was chosen in order to speed the creep process and thus improve the chances for establishing secondary creep in the limited time available.

The first set of tests to be made were terminated prematurely, following evaporative losses from the samples near their contact with the loading platens. This evaporation was apparently caused by air circulation in the narrow gap between the platens and the end of the plastic film wrapped around the ice cylinder. Preferred absorption of radiation at the platens may have been a contributing factor. The tests were run, however, for periods comparable 


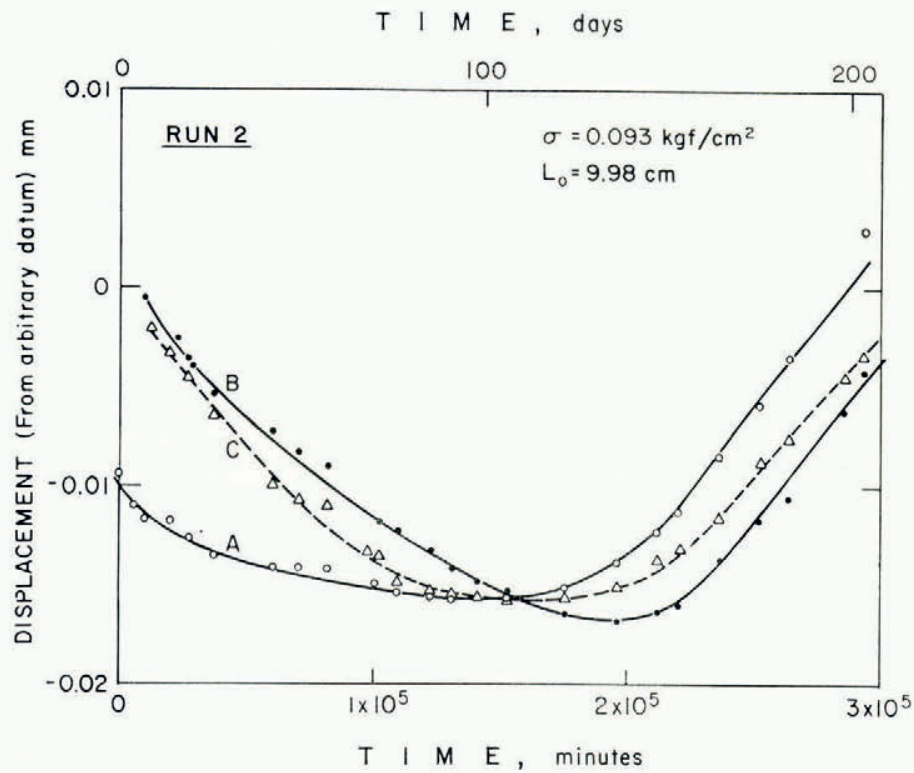

Fig. 2. Low-stress creep curves for fine-grained ice whose crystal orientation was initially random. Test temperature $-2.06^{\circ} \mathrm{C}$. Constant axial compressive stress of $0.093 \mathrm{kgf} / \mathrm{cm}^{2}\left(9 . I \mathrm{kN} / \mathrm{m}^{2}\right)$ after removal of the load of Figure $I$.

with those for the tests by Butkovich and Landauer. Axial stress of $0.43 \mathrm{kgf} / \mathrm{cm}^{2}\left(42 \mathrm{kN} / \mathrm{m}^{2}\right)$ was applied for $\mathrm{I} 30 \mathrm{~h}, 0.20 \mathrm{kgf} / \mathrm{cm}^{2}\left(20 \mathrm{kN} / \mathrm{m}^{2}\right)$ for $\mathrm{I} 25 \mathrm{~h}$, and $0.093 \mathrm{kgf} / \mathrm{cm}^{2}\left(9 . \mathrm{kNN} / \mathrm{m}^{2}\right)$ for $375 \mathrm{~h}$.

For the main series of tests, samples were first placed under constant load, approximating constant stress, at $0.43 \mathrm{kgf} / \mathrm{cm}^{2}\left(42 \mathrm{kN} / \mathrm{m}^{2}\right)$. Creep was allowed to proceed until an apparently

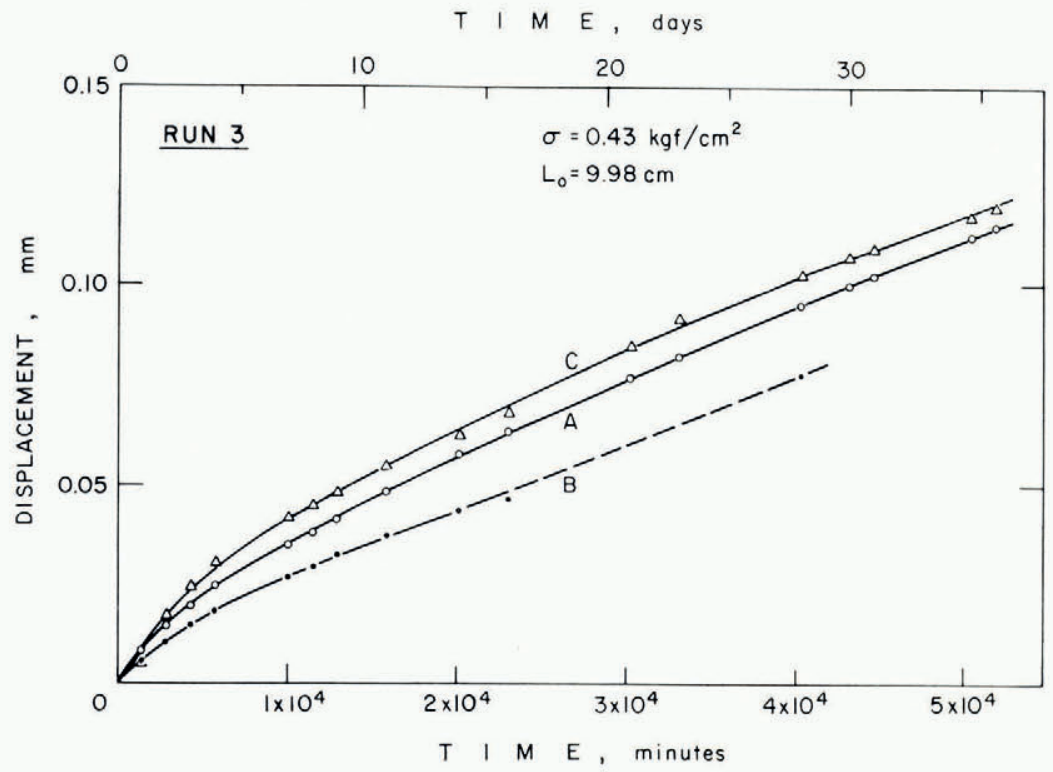

Fig. 3. Low-stress creep curves for fine-grained ice whose crystal orientation was initially random. Test temperature $-2.06^{\circ} \mathrm{C}$. Constant axial compressive stress of $0.43 \mathrm{kgf} / \mathrm{cm}^{2}\left(4^{2} \mathrm{kN} / \mathrm{m}^{2}\right)$ after the loading of Figure 2. 
steady strain-rate developed in all three samples. This took about $16 \mathrm{~d}$ (Fig. I). Axial stress was then lowered to $0.093 \mathrm{kgf} / \mathrm{cm}^{2}\left(9 . \mathrm{I} \mathrm{kN} / \mathrm{m}^{2}\right)$. Under the lower stress, relaxation set in, and creep continued in a direction opposite to the loading direction for about 4 months. Creep then resumed in the direction of the applied load. The total duration of the low-stress stage of the test was $6 \frac{1}{2}$ months, and secondary creep rate for a stress of $0.093 \mathrm{kgf} / \mathrm{cm}^{2}(9 . \mathrm{I}$ $\mathrm{kN} / \mathrm{m}^{2}$ ) was taken as the rate which prevailed during the final 6 weeks (Fig. 2). Stress was then raised to $0.43 \mathrm{kgf} / \mathrm{cm}^{2}\left(4^{2} \mathrm{kN} / \mathrm{m}^{2}\right)$ again, and observations continued for a further 5 weeks (Fig. 3).

The main series of tests was in progress for $8 \frac{1}{2}$ months; the abortive initial tests were in progress for I month. Including set-up time, the whole test program took about i i months to complete.

\section{Results}

Results of the main set of tests are given in Table I.

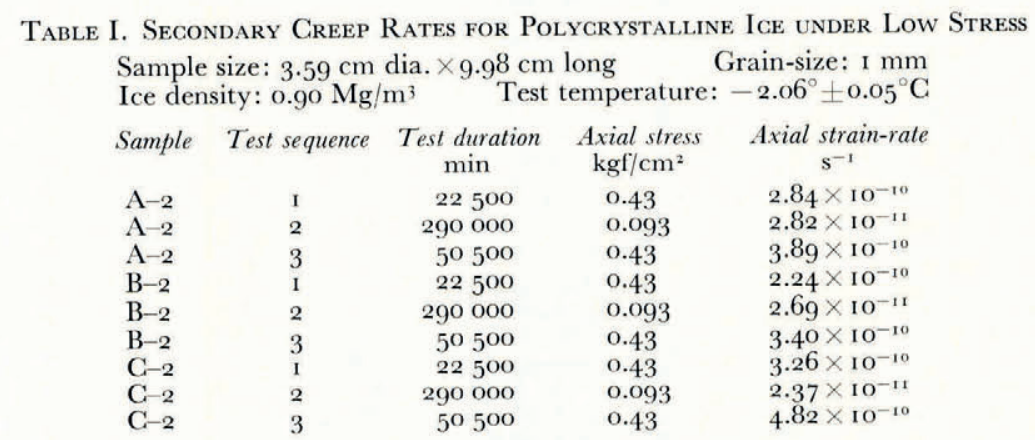

\section{Discussion}

The results show that minimum strain-rate for a stress of $0.43 \mathrm{kgf} / \mathrm{cm}^{2}\left(42 \mathrm{kN} / \mathrm{m}^{2}\right)$ was consistently higher for the second run at that stress, even though the test duration of the second run was almost double that of the first run. The increase of creep rate is attributed to recrystallization during the 200-d period which separated the two runs, although there is no direct evidence to substantiate this. In considering variation of strain-rate with stress, the second set of data for $0.43 \mathrm{kgf} / \mathrm{cm}^{2}\left(42 \mathrm{kN} / \mathrm{m}^{2}\right)$ are more acceptable than the first set since they were obtained at a much smaller time separation from the $0.093 \mathrm{kgf} / \mathrm{cm}^{2}\left(9 . \mathrm{I} \mathrm{kN} / \mathrm{m}^{2}\right)$ determination than were the first set. Strain-rate determinations I and 2 (Table I) were separated by a period of 5 months, whereas determinations 2 and 3 were separated by only 2 weeks.

Using the results from runs 2 and 3 , the exponent of a simple power relation between strain-rate and stress is 1.8 for the stress range 0.1 to $0.5 \mathrm{kgf} / \mathrm{cm}^{2}$ ( 10 to $50 \mathrm{kN} / \mathrm{m}^{2}$ ). This is significantly smaller than the exponent values between 3 and 4 found for high stress ranges.*

There may be questions as to whether minimum strain-rate was properly established in these tests. In the tests at $0.43 \mathrm{kgf} / \mathrm{cm}^{2}\left(4^{2} \mathrm{kN} / \mathrm{m}^{2}\right)$ the minimum strain rate measured in the second, and longer, run was actually greater than that measured in the first run, which tends to dispel the notion that creep was still decelerating. In the test at $0.093 \mathrm{kgf} / \mathrm{cm}^{2}\left(9 \cdot \mathrm{I} \mathrm{kN} / \mathrm{m}^{2}\right)$, strain-rate was measured after a long period of relaxation, and if the strain-rate is in error, it is likely to be too low rather than too high. Thus it is felt that even if the present data are in error, true strain-rates for these stresses are unlikely to be significantly lower than the values measured.

* Note added in proof: Holdsworth and Bull (in press) derive power-law exponents between I.6 and I.9 from observations on deformation of Antarctic glacier ice at $-18^{\circ} \mathrm{C}$ and stress $<60 \mathrm{kN} / \mathrm{m}^{2}$. 
In Figure 4, the results of runs 2 and 3 are plotted on logarithmic scales. The mean strainrate found earlier in three tests at $\mathrm{I} \mathrm{kgf} / \mathrm{cm}^{2}\left(98 . \mathrm{I} \mathrm{kN} / \mathrm{m}^{2}\right)$ and $-2{ }^{\circ} \mathrm{C}$ (Mellor and Smith, I 966 ) has been added, together with a strain-rate for $12 \mathrm{kgf} / \mathrm{cm}^{2}$ (I. I $8 \mathrm{MN} / \mathrm{m}^{2}$ ) given by the results of another set of tests (Mellor and Testa, I969). The line through the data points is drawn so as to give a slope for the high stress range corresponding to the slope established in previous testing (Mellor and Smith, I966).

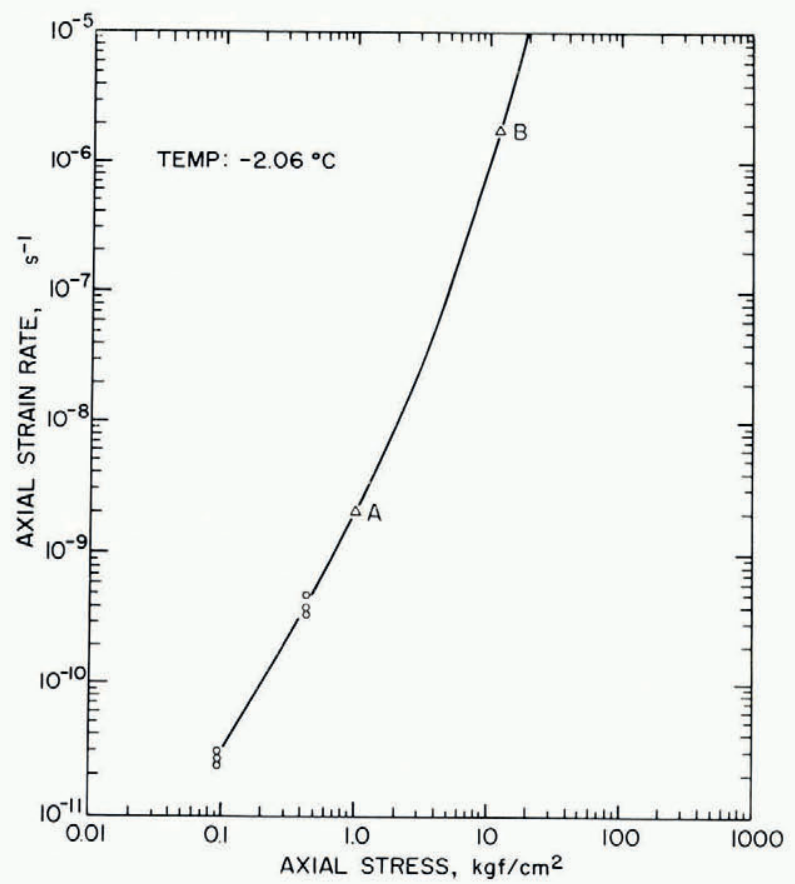

Fig. 4. Axial strain-rate as a function of axial compressive stress for fine-grained, randomly oriented ice at $-2.06^{\circ} \mathrm{C}$. The points marked with triangles are from other papers; point A from Mellor and Smith ( 1967$)$, and point B from Mellor and Testa (1969). The slope at the high stress end corresponds to that established by Mellor and Smith (1967).

In view of results from the present tests, it seems unlikely that Butkovich and Landauer established secondary creep in short-duration tests on polycrystalline ("MPI") ice at very low stress $\left(0.02 \mathrm{kgf} / \mathrm{cm}^{2}\left(2 \mathrm{kN} / \mathrm{m}^{2}\right)\right)$, especially at the lower temperature. Their creep rates for the lowest stresses may well be exaggerated; this would tend to depress the apparent value of the flow-law exponent. Their tests on "commercial" ice are difficult to assess, since the grain-size was so large in comparison with sample size that they cannot be regarded as valid tests for polycrystalline ice.

\section{Conclusions}

The present results are not conclusive in establishing a stress/strain-rate relation for the low stress range, since more protracted testing at the lowest stress might have yielded a somewhat higher strain-rate. They do cast doubt on low-stress laboratory studies in which secondary creep was assumed to have developed after a few days. 
If secondary creep is to be observed directly for polycrystalline ice which initially is randomly oriented, $0.5 \mathrm{kgf} / \mathrm{cm}^{2}\left(50 \mathrm{kN} / \mathrm{m}^{2}\right)$ may be a practical lower limit for employment of the classical constant-load creep test. For lower stresses, test durations are inordinately long; reliability of the test chamber and sample deterioration become serious problems.

MS. received 27 May 1968 and in revised form I2 August 1968

\section{REFERENCES}

Bromer D. J., and Kingery, W. D. 1968. Flow of polycrystalline ice at low stresses and small strains. Journal of Applied Physics, Vol. 39, No. 3, p. $1688-91$.

Butkovich, T. R., and Landauer, J. K. 1960. Creep of ice at low stresses. U.S. Snow, Ice and Permafrost Research Establishment. Research Report 72.

Holdsworth, G., and Bull, C. B. B. In press. The flow law of cold ice: investigations on the Meserve Glacier, Antarctica.' (In Special Committee on Antarctic Research. International Symposium on Antarctic Glaciological Exploration, Hanover, N.H., September 1968.)

Mellor, M., and Smith, J. H. 1967. Creep of snow and ice. (In Ōura, H., ed. Physics of snow and ice: international conference on low temperature science. … 1966. ... Proceedings, Vol. 1, Pt. 2. [Sapporo], Institute of Low Temperature Science, Hokkaido University, p. 843-55.)

Mellor, M., and Testa, R. 1969 . Effect of temperature on the creep of ice. Journal of Glaciology, Vol. 8, No. 52, p. $\mathrm{I} 3 \mathrm{I}-45$. 